\title{
Bankers' Stock Options, Risk-Taking and the Financial Crisis
}

\author{
Marizah Minhat ${ }^{*}$ \\ School of Accounting, Financial Services and Law \\ Edinburgh Napier University \\ Craiglockhart Campus \\ Edinburgh EH14 1DJ \\ Scotland \\ United Kingdom \\ Phone: + 441314554438 \\ Fax: + 441314554460 \\ E-mail: m.minhat@napier.ac.uk
}

\author{
Mazni Abdullah \\ Department of Accounting \\ Faculty of Business and Accountancy \\ University of Malaya \\ 50603 Kuala Lumpur \\ Malaysia \\ Phone: + 60379673965 \\ Fax: + 60379673810 \\ E-mail: mazni@um.edu.my
}

\footnotetext{
* Corresponding author.

The authors would like to thank the Managing Editor and anonymous reviewers of the Journal of Financial Stability, as well as participants at the 2010 Conference on Corporate Governance and the Global Financial Crisis at the Wharton School of the University of Pennsylvania, for comments and suggestions on an earlier version of this paper. Financial support from the Edinburgh Napier University, the University of Malaya, and the Institute of Chartered Accountants of Scotland (ICAS) are acknowledged.
} 


\title{
Bankers' Stock Options, Risk-Taking and the Financial Crisis
}

\begin{abstract}
This study investigates the relationship between the use of stock options and bank risk in the context of the 2007-2008 financial crisis for banks that are authorised to accept deposits in the United Kingdom. These banks are affected by the European regulation on variable pay, but, to our knowledge, their usage of stock options has not been examined in previous studies. Paying bankers with stock options can generate two types of managerial incentives, namely, incentives to improve performance and incentives to take risk. Controlling for incentives to improve performance, we find that banks' total risk and insolvency risk increase with the risk-taking incentives induced by stock options. We also find that this relationship is more pronounced surrounding the crisis period. The findings of this study can serve as institutionally relevant empirical support for the European regulation on variable pay.
\end{abstract}

Keywords: Executive Pay; Stock Options; Vega; Bank Risk-taking; Financial Crisis JEL classification: G2, G3 


\section{Introduction}

There has been widespread concern that bankers' variable pay has encouraged excessive risk-taking at financial institutions; this was claimed to have precipitated the 2007-2008 financial crisis (Bebchuk and Spamann, 2010; Financial Services Authority (FSA), 2009). According to the European Banking Authority (EBA), the ratio of variable-to-fixed pay of high earners (with pay brackets of EUR 1 million or more) at financial institutions in the United Kingdom (UK) was as high as $611 \%$ in 2010, 346\% in 2011 and 370\% in 2012. In 2013, Capital Requirements Directive IV (Article 94, Directive 2013/36/EU) was introduced to limit the ratio of variable-tofixed pay of bankers to $100 \%$ (or $200 \%$ with the backing of a supermajority of shareholders).

However, in the absence of relevant empirical evidence on the net risk-taking effect of variable pay, limiting variable pay can be seen as a contentious regulatory response to the issue of excessive risk-taking by financial institutions (Murphy, 2013). Such regulation was also challenged by the UK Treasury. Our study contributes relevant empirical evidence to rationalise the need for regulation.

The Directive defines variable pay as payments or benefits that depend on performance, which certainly includes cash bonuses and stock options. While the regulation on cash bonuses necessarily assumes that bonuses must drive bank risk, ${ }^{1}$ there is very limited empirical evidence on the role of other components of variable pay, such as stock options, that can be linked to the latest financial crisis. We feel that providing empirical evidence that relates to the crisis period will be useful in rationalising the European regulation on variable pay, especially when the use of

\footnotetext{
${ }^{1}$ For example, the FSA (2009: 18) highlights that "Our concern in our review was, however, as much with the treatment of cash bonuses, which as noted above remain a significant proportion of total bonuses and typically not deferred."
} 
stock options is claimed to have provided bankers with incentives to take excessive risks during the time leading up to the financial crisis (Bebchuk and Spamann, 2010).

Our study differs in several ways from prior studies that examine stock options use and bank risk-taking in the United States (e.g., Belkhir and Chazi, 2010; Chen et al., 2006; Fahlenbrach and Stulz, 2011; Houston and James, 1995). First, we examine a sample of banks incorporated in 29 countries that are authorised to accept deposits in the United Kingdom (UK). From a policy-making perspective, these are the banks that are affected by the recent regulatory reform, because these banks are involved in managing deposits in the $\mathrm{UK}^{2}$ To our knowledge, the use of stock options across banks operating in the UK has not been previously investigated; hence, empirical evidence in this area is currently non-existent. There is a real need to enrich the literature with empirical evidence derived from these banks, as they are relevant regulatees who are affected by the European regulation on variable pay. Our study contributes to filling this gap.

Second, the data used in previous studies on bank risk-taking are either significantly outdated (e.g. Chen et al., 2006; Houston and James, 1995) or do not include the crisis years (e.g. Belkhir and Chazi, 2010; Fortin et al., 2010). Therefore, the link between the use of stock options in bankers' pay and the latest financial crisis cannot be directly inferred from their findings. It remains largely unknown whether the financial crisis was due in part to the use of stock options in bankers' pay. If the statistically positive relationship between banks' risk and the use of bankers' stock options can be observed over time, one may question why the crisis occurred when it did. To address this question, data for non-crisis, pre-crisis and crisis periods are

\footnotetext{
${ }^{2}$ Given the global reach of major banks and the very significant role of major non-UK-listed banks in London, the Walker Review Secretariat (2009) considers it is appropriate and necessary for broadly comparable disclosure on risk and remuneration to be implemented by FSA-authorised banks that are UK-domiciled subsidiaries of non-resident entities.
} 
examined. Analysing different periods will provide clearer insight into the dynamic and significance of the relationship between banks' risk and the use of bankers' stock options over different economic climates. We do not underestimate the relevance of crisis period that triggered policy makers to regulate variable pay. Our study enriches the literature with empirical evidence that is relevant and generalisable to the context and time period in question.

Our study documents three important findings. First, we find that banks' total risk increases as bankers' risk-taking incentives (generated through stock options) increases. Second, as a novel contribution of this study, we find that banks' z-scores decrease as bankers' risk-taking incentives increase, which suggests that banks' greater insolvency risk is related to bankers' higher risk-taking incentives induced by stock options. The empirical results are robust after controlling for potential endogeneity of risk-taking incentives. Risk-taking incentives also appear to determine banks' risk when lagged values are used as part of robustness checks. Third, we also find that the relationship between banks' risk and option-induced risk-taking incentives is more pronounced surrounding the crisis period. Overall, our findings are consistent with previous empirical evidence that suggests stock options induce bankers to increase bank risk-taking. They are also consistent with the commonly held view that bank failures and the financial crisis are unintended consequences of such perverse incentives (Bebchuk and Spamann, 2010). Therefore, we suggest that there is a case for regulators to regulate bankers' variable pay, such as stock options.

The remainder of the paper is organised as follows. Section 2 discusses the relevant literature. Section 3 presents the hypotheses. Section 4 describes the empirical tests. Section 5 describes the data and descriptive statistics. Section 6 reports the empirical results. Section 7 provides conclusions. 


\section{Literature Review}

\subsection{Risk-Related Incentive Problems}

Studies on executive compensation have recognised that the use of stock options in executive pay can help mitigate risk-related incentive problems that arise between managers and shareholders of a firm (Guay, 1999). Risk-related incentive problems manifest when managers forego investment in risky projects due to their risk aversion, which is incongruent with the interests of firm shareholders who are less risk-averse (Rajgopal and Shevlin, 2002). In discussing the moral hazard problem of banks, Bebchuk and Spamann (2010: 255) argue that "those who provide equity capital have an excessive incentive to take risk" with a view to maximising return. ${ }^{3}$ Stock options can be used to get bank managers to efficiently pursue shareholders' interests in this way.

\subsection{Stock Options as Bankers' Risk-Taking Incentives (Vega)}

The use of stock options not only mitigates risk-related incentive problems, but also discourages option holders from hedging against risk (e.g., Aretz and Bartram, 2010; Rajgopal and Shevlin, 2002). This is because stock options have an important feature that can influence bankers' attitudes towards risk. This feature is described as stock options' vega, which is used in this study to measure bankers' risk-taking incentives.

As in previous studies (e.g., Belkhir and Chazi, 2010; Rajgopal and Shevlin, 2002), a stock option's vega is defined as the sensitivity of a stock option to a change

\footnotetext{
${ }^{3}$ Gorton and Rosen (1995) argue that similar attitude can be held for bank executives who are also shareholders of the bank they manage. Several factors may explain why banks' shareholders will have great incentives to encourage their managers to pursue risky investments. These factors have been widely discussed under the 'moral hazard' theme in the banking literature (e.g., Bebchuk and Spamann, 2010; Ponce, 2010; Jeitschko and Jeung, 2005; Gorton and Rosen, 1995; Merton, 1977). The presence of limited liability coupled with deposit insurance (e.g., the Financial Services Compensation Scheme in the UK) and lenders of last resort (e.g., government bailouts) are factors that can induce banks' shareholders (and managers with aligned interests) to bear excessive risk with a view to maximising return.
} 
in stock price volatility. Guay (1999) establishes that stock options will significantly increase the sensitivity of a manager's pay-related wealth to the underlying firm's stock return volatility, which he describes as equity risk. Given that stock options' value increases with firms' equity risk, managers with stock options will have a greater incentive to undertake all risky positive NPV investments with a view to increasing the underlying firm's equity risk and consequently the value of their stock options. The incentive to increase equity risk arises due to stock options' asymmetric payoffs, whereby managers can cash out profit when the underlying firm's share price increases as a result of successful risky investment, but will not suffer material cash outflow if the risky project fails.

The relation between executive stock options and risk-taking by non-financial firms has been documented in several studies (Coles et al., 2006; Rajgopal and Shevlin, 2002). By examining a sample of oil and gas producers, Rajgopal and Shevlin (2002) find that option-induced risk-taking incentives are positively related with risky future exploration activities. They also find that such risk-taking incentives are negatively related with oil price hedging. Their findings suggest that stock options can induce managers to increase risk rather than manage risk. In addition, Coles et al. (2006) find that option-induced risk-taking incentives motivate riskier policy choices, such as more investment in research and development, low investment in property, plant and equipment, fewer lines of business and higher leverage.

However, not many studies in banking examine the potential moral hazard arising from the use of stock options in bankers' pay. Although some studies indicate that bank managers may have several reasons for favouring increases in banks' investment risk, the role of stock options is not mentioned (e.g., Jeitschko and Jeung, 2005; Gorton and Rosen, 2002). It is also observed that previous empirical findings 
on the role of stock options are somewhat mixed, and have no direct link to the latest financial crisis (Belkhir and Chazi, 2010; Chen et al., 2006; Fortin et al., 2010; Houston and James, 1995).

For example, based on a sample of commercial banks during the period 19801990, Houston and James (1995) find no evidence that the use of stock options (measured by the ratio of options granted to cash pay) increases the level of banks' risk (measured by the variance in banks' stock returns). In a later study, Chen et al. (2006) examine commercial banks for the period 1992-2000 and find that the use of stock options (measured by the ratio of the value of stock options to total pay) increased tremendously in the banking industry during this time. The substantial presence of stock options could explain why Chen et al. (2006) find a significant relationship between option-based pay and market-based measures of banks' risk. Similar results are documented in Fortin et al. (2010), who examine the use of stock options among banks in the United States for the pre-crisis year of 2005.

\section{Hypotheses}

The empirical studies discussed above do not distinguish between the two types of managerial incentives created by stock options, namely, incentives to improve performance and incentives to take risk. A more recent study by Belkhir and Chazi (2010) examines bank holding companies in the United States during a pre-crisis sample period of 1993-2006. By controlling for option-induced performance incentives (as measured by delta), they find that larger banks with better investment opportunities and those that operate in a deregulated environment tend to implement higher options' vega (i.e., risk-taking incentives). They also document a significant 
relationship between vega and market-based measures of banks' risk. These empirical findings lead us to form the first hypothesis:

Hypothesis 1. There is a positive relationship between banks' total risk and option-induced risk-taking incentives.

Previous studies use market-based risk measures to proxy for banks' risk (e.g., Belkhir and Chazi, 2010; Chen et al., 2006). Our study contributes to the existing literature by also considering a more extreme measure, which is insolvency risk. Some studies (e.g., Laeven and Levine, 2010; Pathan, 2009) use z-score to measure banks' insolvency risk. This is also a contributing aspect of our study, because several banks in the United Kingdom fundamentally reached insolvency state (or were bailed out) during the financial crisis (e.g., The Royal Bank of Scotland). To our knowledge, empirical evidence on the relation between banks' insolvency risk and bankers' risktaking incentives is scarce. Despite the pressure for regulatory reform on stock options (Bebchuk and Spamann, 2010) and the recent regulatory cap on variable-tofixed pay ratio (Article 94, Directive 2013/36/EU), it is largely unknown to what extent such variable pay is capable of producing risk-taking incentives that can increase banks' insolvency risk. Previous empirical findings derived from marketbased risk measures lead us to form the second hypothesis:

Hypothesis 2. There is a positive relationship between banks' insolvency risk and option-induced risk-taking incentives.

One notable gap in previous studies (e.g., Fortin et al., 2010) is that the findings are only applicable to the period before the financial crisis. If the relation between stock options use and banks' risk is positively stable over time, one may 
question why the crisis occurred when it did. To address this question, we divide our regression analysis into three periods: non-crisis, pre-crisis and crisis periods. This allows us to examine whether the relationship between risk-taking incentives and banks' risk becomes more pronounced towards the crisis period. This leads to our third hypothesis:

Hypothesis 3. The relation between banks' risk measures and option-induced risk-taking incentives strengthens surrounding and during the financial crisis period.

\section{Empirical Tests}

The following regression models are used to estimate the relation between banks' risk and risk-taking incentives induced by stock options as measured by vega:

$$
\begin{aligned}
& \text { Total risk }_{j t}=\alpha+\beta_{1} \text { Vega }_{j t}+\sum_{2}^{n} \beta_{n} \text { Controls }_{j t}+\gamma_{k}+\delta_{t}+\varepsilon_{t}
\end{aligned}
$$

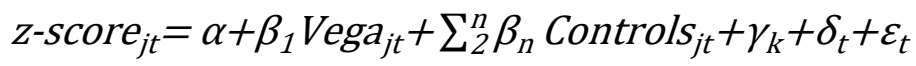

To test the first hypothesis, the dependent variable Total risk $_{j t}$ represents stock return volatility for bank $j$ during period $t$. Following many studies (e.g., Belkhir and Cazi, 2010; Fortin et al., 2010; Pathan, 2009; Chen et al., 2006), the bank's total risk is calculated as the standard deviation of the bank's daily stock returns for a given year. This measures the deviation of the bank's stock returns from historical returns, which considers both systematic and unsystematic risks of the underlying stock.

To test the second hypothesis, the inverse of the probability of insolvency as measured by z-score is used as another proxy for bank risk, which is a common approach in previous studies (e.g., Laeven and Levine, 2010; Pathan, 2009). A higher 
$\mathrm{z}$-score indicates that the bank is more financially stable. Similar to the approach in Laeven and Levine (2010), the natural logarithm of z-score is used because the distribution of z-score values is highly skewed.

In both Equations (1) and (2), the independent variable Vega $_{j t}$ denotes bankers' risk-taking incentives induced by stock options. The regression models also include additional controls for year $\left(\delta_{t}\right)$ and country-specific factors $\left(\gamma_{k}\right) . \varepsilon_{j t}$ is an idiosyncratic error term. A country dummy is used to control for country-specific factors that may influence the compensation policies of banks incorporated in certain countries. Other control variables are factors deemed to be associated with bank risktaking as identified in the literature. These are: option-induced performance incentives as measured by delta (e.g., Fahlenbrach and Stulz, 2011), bank or firm size (e.g., Coles et al., 2006), derivatives usage (e.g., Rogers, 2002) and proportion of nonexecutive directors on a bank's board (e.g., Pathan, 2009). All variables are listed and defined in the Appendix. For the sake of brevity, the influence of these factors on bank risk-taking will be discussed in the results section.

To address the third hypothesis, subsampling analyses based on non-crisis, pre-crisis and crisis years were undertaken. Non-crisis refers to the year 2005, which is remote from the crisis years. Non-crisis years are basically the time period that prior studies have focused on (e.g., Belkhir and Chazi, 2010; Chen et al., 2006; Fortin et al., 2010). The pre-crisis year 2006 is immediately before the crisis; in this year we anticipate the relation between executive vega and bank risk measures will begin to strengthen. A similar expectation is held for the crisis years of 2007 and 2008. Many studies have recognised that the financial crisis started to unfold in 2007 (e.g., Fortin et al., 2010; Brunnermeier, 2009). We follow these studies, and define the crisis years as 2007 and 2008 . 


\section{Data and Descriptive Statistics}

\subsection{Sample selection and description}

Our study examines banks that are authorised by the Financial Services Authority (FSA) to accept deposits in the United Kingdom. The sample period covers the years from 2005 to 2008. As shown in Table 1 (Panel A), 150 of these banks were incorporated in the United Kingdom, 98 banks were incorporated inside the European Economic Authority (excluding the United Kingdom) (EEA Ex-UK) and 83 were incorporated outside the EEA. With a view to producing a balanced panel and clean analysis that will allow us to observe the same sample of banks over the years, 202 from a total of 331 banks (i.e., 61\%) were eliminated from the sample because one or more of their annual reports published during the 2005-2008 period was not available.

Insert Table 1 about here

Non-disclosure of detailed executive stock options data further reduced the sample size. Sixty-nine banks (53\%) were eliminated from the remaining balance of 129 banks, producing a sample of 60 banks: 11 banks (18\%) were incorporated in the United Kingdom, 21 banks (35\%) were incorporated inside the EEA Ex-UK and 28 banks $(47 \%)$ were incorporated outside the EEA. The sample consists of banks incorporated in 29 countries. ${ }^{4}$ Since our study covers a period of four years (i.e., 2005-2008), the sample consists of a balanced panel of 240 bank-year observations.

Panel B of Table 1 shows that of the 240 bank-year observations (i.e., 60 banks), 76 bank-years (i.e., 19 banks) had disclosed not using stock options in their

\footnotetext{
${ }^{4}$ The countries are the United Kingdom, the United States, Australia, France, Spain, Saudi Arabia, Germany, Canada, Switzerland, India, Israel, Malaysia, Sweden, Singapore, South Africa, Ireland, Italy, Luxembourg, the Netherlands, Portugal, Austria, Turkey, China, Denmark, Hong Kong, Indonesia, Korea, Sri Lanka and Thailand.
} 
executive compensation packages. Sixty-three per cent of these banks were incorporated outside the EEA. Thirty-six bank-years (i.e., 9 banks) disclosed using stock options without providing adequate details in their annual reports to permit analysis. We suspect that these banks may have awarded stock options in the past and may well have chosen not to grant stock options during our sample period. Similar to some industrial firms, some banks may choose not to grant stock options for every year. This happened to six bank-years in 2007-2008.

In addition, stock options were not granted during 2005-2008 in 49\% (i.e., 118/240) of the studied bank-years. Therefore, our first subsample consists of 118 bank-years in which executive directors were not awarded with stock options during the sample period. About 55\% of this subsample is made up of banks incorporated outside the EEA. This observation may suggest that the use of stock options has not been as widespread in some countries. ${ }^{5}$

The second subsample consists of 122 bank-years in which executive stock options were granted, and in which adequate details of option grants were disclosed in annual reports that enables us to calculate the options' vega. This subsample of 122 bank-years is well-diversified because $29 \%, 33 \%$ and $38 \%$ of them are incorporated in the UK, inside the EEA Ex-UK and outside the EEA, respectively.

\subsection{Descriptive statistics}

Table 2 reports the descriptive statistics for the variables used in this study. Due to a lack of research, the recent magnitude of executive stock options in the UK banking

\footnotetext{
${ }^{5}$ We have no convincing argument to suggest that the compensation structures of the US banks has been replicated by banks operating elsewhere. There could be several reasons to explain this phenomenon, which is beyond the scope of our current study.
} 
industry remains largely unknown. ${ }^{6}$ For the full sample (i.e., 240 observations), the average ratio of stock options' value to the total executive compensation is $24 \%$, which is comparable to the $26 \%$ reported in Chen et al. (2006). The average BlackScholes value of accumulated stock options is $£ 5.3$ million. The average magnitude of stock options is much greater for the sample that considers only bank-years with stock option grants (i.e., 122 observations). For this subsample, the average ratio of stock options' value to total pay is $45 \%$, and the average options' value is $£ 10.3$ million. Therefore, stock options constitute a substantial component of executive pay.

Insert Table 2 about here

The average options' vega, or risk-taking incentives, which is the focus of our study, is 0.03 for the full sample and 0.05 for the subsample. For the subsample of 122 bank-years, the value of stock options changes by $5 \%$, for a $1 \%$ change in the underlying stock volatility. This is comparable to the 0.06 reported for a sample of US banks in Belkhir and Cazi (2010). This figure is also lower than the 0.09 reported for US industrial firms (Belkhir and Cazi, 2010). Comparing the stock options' vega of banks with that of industrial firms, however, is not important. This is because vega can induce bankers to increase banks' risk, and a failure to control this may result in excessive risk-taking that can adversely affect other stakeholders in the economy, given the intermediary role that banks play.

It is common to observe vega to be much lower than delta (see, for example, Coles et al., 2006). The average option's delta, as a measure of option-induced

\footnotetext{
${ }^{6}$ A survey of the seven largest banks in the UK over the 2003-2007 period does not reveal the magnitude of bank executives' stock options (Marshall, 2009).
} 
performance incentive, for the full sample is 0.24 . For the sample that considers only bank-years with stock option grants, the average delta is 0.46 . This means that a stock option will change in value by 46 pence for every pound of change in the value of underlying bank stock. This figure is lower than the 0.64 reported in Lee et al. (2007) for industrial firms in the UK. According to John and Qian (2003), low payperformance sensitivity is an accepted feature of the banking industry. ${ }^{7}$

Following the approach in Core and Guay (1999), the average stock option's delta is multiplied by $1 \%$ of the bank's stock price, which yields an average of $£ 65,618$. Our figure is higher than the $\$ 60,587$ reported in Belkhir and Cazi (2010) for a sample of banks operating in the US. In the case of stock option's vega, our figure is $£ 2,136$, which is lower than the $\$ 5,935$ reported in the US. It is obvious that direct comparisons are not possible because different sample periods are used, but it seems that risk-taking incentives are higher among bank executives operating in the US. ${ }^{8}$

The average stock return volatility for the full sample is $1.9 \%$, which is slightly higher than the $1.8 \%$ reported in Chen et al. (2006). The average of the natural logarithm of $\mathrm{z}$-score is 1.23 , which is lower than the 2.88 reported in Laeven and Levine (2010). A higher total risk and insolvency risk observed in our study can be most likely attributed to the high volatility and insolvency risk faced by our sample banks around the financial crisis period.

\section{Empirical Results}

\subsection{Bank risk and option-induced risk-taking incentives (vega)}

\footnotetext{
${ }^{7}$ John and Qian (2003) document that the pay-performance sensitivity in banks is $\$ 4.7$ per $\$ 1,000$ increase in shareholder value. This is lower than the \$6 per \$1,000 increase in shareholder value in manufacturing firms.

8 This observation is consistent with Conyon and Murphy's (2000) suggestion that American executives may be less risk-averse than their counterparts elsewhere.
} 
The relation between banks' risks and risk-taking incentives induced by stock options is examined using multivariate regressions to control for the effect of variables that are significantly related to stock volatility and z-score. Vega is used instead of value of stock options, as a more appropriate measure of bank executives' risk-taking incentives. We reduce the possibility of a serious multicollinearity problem by ensuring that the variance inflations factors (vif) for independent variables in the Ordinary Least Squares (OLS) regressions are less than 10. The regression results are presented in Table 3.

Insert Table 3 about here

As described in Table 3, the dependent variable for Column 1 is banks' total risk, as measured by banks' stock return volatility. Column 1 reports that in the presence of performance incentives (delta), vega increases with banks' total risk. Delta is an important control variable because performance incentives constrain the risk-taking incentives provided through vega (Coles et al., 2006). This is evidenced by the observed negative relationship between delta and banks' total risk. A lower proportion of non-executives on board may imply greater monitoring difficulties to restrain executives' risk-taking. This argument can well explain the observed negative relationship between a bank's total risk and the proportion of non-executives on the board. Another interesting observation is that banks with higher total risk are those classified as derivative traders. ${ }^{9}$

The results reported in Column 1 of Table 3 are consistent with the first hypothesis, which suggests that stock options structured with greater risk-taking

\footnotetext{
9 The relation between derivative trading and bank risk-taking is an interesting aspect for further investigation, but is beyond the scope of this study.
} 
incentives will induce bankers to increase banks' risk. To what extent the optioninduced risk-taking incentives contribute to a bank's failure is another interesting issue to explore. Empirical results to address this issue, which is related to our second hypothesis, are presented in Column 3 of Table 3.

Column 3 of Table 3 reports the results on the relation between banks' insolvency risk and risk-taking incentives induced by stock options. The dependent variable is the natural logarithm of z-score. A bank with a lower z-score is exposed to higher insolvency risk. Consistent with the second hypothesis, Column 3 shows that after controlling for stock options' delta, banks with higher stock options' vega are associated with lower z-scores. Our findings suggest that banks that implement higher vega for their managers will be less financially stable, and hence exposed to greater insolvency risk. Our results are robust after controlling for several other factors that may also influence banks' insolvency risk.

\subsection{Endogeneity/causation issues}

While the preceding discussion is based on the assumption that stock options' vega determines bank risk, it is also possible that causation works the other way round. Vega and bank risk could also be jointly determined by some unobservable factors. To isolate causation and address potential endogeneity problems, we estimate simultaneous systems of equations (i.e., 2SLS), which is a common approach used in many studies (e.g., Rogers, 2002; Coles et al., 2006).

The jointly determined variables in question are vega and bank risk. In the first stage regression, vega is set as a dependent variable. The specification used to predict vega is based on variables commonly used in the literature (e.g., Guay, 1999; Rogers, 2002; Rajgopal and Shevlin, 2002; Coles et al., 2006), which are: executive cash 
compensation, delta, bank risk, size, growth opportunities, country dummy and year dummy. These variables are regressed on vega in order to produce the predicted values of vega. Cash compensation and growth opportunities are set as instrumental variables because the unreported regressions show that they do not affect bank risk.

The second stage regression sets the predicted value of vega as an explanatory variable that can explain bank risk. \%Ownership (i.e., the percentage of equity ownership held by bank executives) is added as an additional explanatory variable to proxy for risk aversion, which is an unobservable factor that can influence bankers' characteristics or investment decisions. The results of the 2SLS are reported in Table 3 (Columns 2 and 4). In a further robustness check, we also mitigate the causality concern by using one-year lagged values of vega as determinants of bank risk. The results are consistent with those reported in Table $3 .{ }^{10}$

\subsection{Banks' total risk and option-induced risk-taking incentives (vega) during non- crisis, pre-crisis and crisis periods}

Our empirical results so far are consistent with the findings of previous studies regarding the positive relation between executive stock options' vega and bank risktaking (e.g., Belkhir and Chazi, 2010). Our study also contributes to the existing literature by examining the interaction between executive vega and bank risk-taking during non-crisis, pre-crisis and crisis periods. This approach, which has not been implemented in previous studies, can provide a clear insight about the commonly held view that the financial crisis was caused in part by the use of stock options in bankers' pay. The results related to our third hypothesis are presented in Tables 4 and 5 .

\footnotetext{
${ }^{10}$ For the sake of brevity, the results are not reported here, but are available from the authors upon request.
} 
The dependent variable in Table 4 is banks' total risk. Column 1 reports the results for the non-crisis period, which refers to the year 2005. Throughout this period, the relation between stock options' vega and banks' total risk is not statistically significant. As shown in Column 2, the relation begins to strengthen significantly during the pre-crisis period of 2006. A similar trend is observed throughout the crisis period, as reported in Column 3. Based on these results, it can be gathered that the relation between options' vega and banks' total risk is not stable over time. It seems that banks' total risk began to increase more in tandem with vega surrounding the crisis period. In unreported statistics, we observe that the dollar value of stock options’ vega increased tremendously, by $68 \%$ on average, from $£ 1,607$ in 2005 to $£ 2,705$ in 2006. This suggests that bank executives had much greater risk-taking incentives surrounding the crisis period than in the period before the crisis. It is plausible that this factor induced even greater risk-taking among banks, which eventually reached its peak when the crisis erupted in the following year.

\subsection{Banks' insolvency risk and option-induced risk-taking incentives (vega) during non-crisis, pre-crisis and crisis periods}

The dependent variable in Table 5 is banks' z-score as the inverse of insolvency risk. As reported in Column 1, the relation between stock options' vega and banks' z-score is not statistically significant throughout the non-crisis year of 2005. As shown in Column 2, the relation begins to strengthen significantly surrounding the crisis period. A similar trend is observed throughout the crisis period, as reported in Column 3. Similar to the case of banks' total risk, the relation between vega and banks' 
insolvency risk seems unstable over time. Banks' insolvency risk began to increase more in tandem with vega around the crisis period. These results suggest that a large increase in stock options' vega from 2005 to 2006 did influence bank managers to increase the riskiness of their banks' investment portfolios, which simultaneously placed the banks in an unstable financial position.

Insert Table 5 about here

There are at least two alternative arguments that suggest that even during the height of the crisis bank managers acted recklessly, and shifted towards even riskier investments. First, shareholders, together with bank managers with stock options, may have behaved this way due to the presence of limited liability. Given the presumably deteriorating value of the banks at this point, they have had little to lose from the downside of potentially risky investment projects, but stand to gain enormously had the projects turn out to be successful (Louise, 2011). This implies that the 'limited liability' condition induced them to shift towards riskier investments during crisis, which can be costly to creditors. ${ }^{11}$

Second, during a crisis period, debt overhang may impede shareholders and hence bank managers, as their agents, from executing positive NPV projects, because the gains from those projects partially or primarily will go to existing creditors instead of shareholders (Myers, 1977). In this scenario, the risk-taking incentives induced by stock options can be very useful to induce managers of distressed banks presumably facing a debt overhang scenario to continue pursuing risky investments, with the hope

\footnotetext{
${ }^{11}$ This line of argument has been accepted by legal scholars to justify greater creditor protection during financial crisis or a firm's insolvency (Louise, 2011).
} 
of creating value. During such crisis periods, managers with stock options will be induced to continue investing in risky loans to create value, although this might benefit debtholders more than shareholders of the distressed banks. This line of argument does suggest that managers may shift towards still riskier investments during a crisis period, when they are incentivised to do so through vega. Such reckless risk-taking behaviour explains why bankers suffered large losses during the crisis (Bebchuk and Spamann, 2010).

Finally, consistent with the observations made by previous studies (e.g., Belkhir and Chazi, 2010; Fortin et al., 2010; Chen et al., 2006), Column 1 of Table 3 reports that smaller banks, as in the case of smaller firms, tend to be riskier than larger banks, as measured by their stock returns volatility. Iliquidity may play a role, because the largest banks are the main beneficiaries of significant too-big-to-fail implicit subsidies. However, the inverse link between bank size and bank riskiness is disputable, and may indeed be a subject for further research. For example, prior studies find that large banks tend to be associated with greater insolvency risk (e.g., Bhagat et al., 2012; Pathan, 2009). As reported in Columns 3 and 4 of Table 3 and Columns 2 and 3 of Table 5, larger banks seem to have been exposed to higher insolvency risk, especially surrounding and during the crisis period. One may argue that this can be consistent with some anecdotal evidence of bailouts involving large and systematically important banks such as the Royal Bank of Scotland and Lloyds TSB in the United Kingdom.

\section{Conclusions}

This study is built upon the often-held view that stock options induce managers to invest in risky investment activities (e.g. Coles et al., 2006; Rajgopal and 
Shevlin 2002). Regulating variable pay has been the main agenda of European regulators as part of their post-crisis response. Although prior studies (e.g., Bebchuk and Spamann, 2010; Belkhir and Chazi, 2010; Chen et al., 2006) have linked banks' risk-taking to the use of stock options in bankers' pay, their empirical evidence does not directly relate to the crisis period. This research gap motivated our study to provide empirical evidence on the relation between bankers' stock options and banks' risk-taking in the context of the 2007-2008 financial crisis. Most importantly, our study contributes empirical evidence derived from banks that are affected by the European Directive. We are not aware of previous studies on bankers' stock options that examine such a data set. Such empirical evidence can help enrich the discourse about the relative restriction on variable pay, which is imposed through the implementation of CRD IV (Article 94, Directive 2013/36/EU).

We find that banks' total risk and insolvency risk increases with the risktaking incentives induced by bankers' stock options. The empirical results are robust after controlling for option-induced performance incentives and potential endogeneity of vega. Risk-taking incentives also appear to determine banks' risk when lagged values of vega are used during robustness checks. We also find that this relationship is more pronounced surrounding the crisis period. The subsampling results imply that the strength of a short-term (i.e., yearly) relation between vega and banks' risk measures is dynamic. Our findings, taken together, are consistent with the often-held view that paying bankers with stock options had induced them to increase banks' risktaking as occurred during the crisis period (e.g., Bebchuk and Spamann, 2010).

The findings of this study shed further light on, and enrich our understanding of, the concern that bankers' stock options played an important role in fuelling the financial crisis. By implication, one can suggest that, apart from other factors already 
established in the literature, the financial crisis was due in part to the use of stock options in bankers' pay. We therefore suggest that the implementation of a relative cap on variable pay through the implementation of CRD IV should be welcomed as part of regulatory efforts to restrict the use of perverse incentives induced by stock options.

Nevertheless, there are caveats and suggestions for future research. First, the limited scope of our study prevents us from (definitively) suggesting whether the level of variable pay or the ratio of variable-to-fixed pay should be regulated. A more deliberate effort to prohibit the use of stock options (such as that imposed on the recipients of the Troubled Asset Relief Program (TARP) in the US) could also be worthy of consideration (Murphy, 2013). The evaluation of these alternative policy prescriptions is very much an interesting subject matter for further debate and research. Second, it is also important to bear in mind that a chosen policy prescription may not yield the desired result, and may even lead to unintended consequences. For example, curtailing variable pay through taxes may lead to even higher variable pay (Dietl et al., 2013). Finally, depending on data availability, future research can also investigate the influence of option-induced risk-taking incentives on investment decisions. A small but growing number of studies have started to explore managers' investment decisions (e.g., Huang et al. (2011) on fund managers' investment decisions). Greater disclosure in the future will allow researchers to determine to what extent bankers' investment decisions can be induced through the use of stock options. 


\section{References}

Aretz, K., S. M. Bartram, 2010. Corporate hedging and shareholder value. Journal of Financial Research. 33, 317-371.

Bebchuk, L. A., H. Spamann, 2010. Regulating bankers' pay. Georgetown Law Journal. 98, 247-287.

Belkhir, M., A. Chazi, 2010. Compensation vega, deregulation and risk-taking: Lessons from the US banking industry. Journal of Business, Finance and Accounting. $37,1218-1247$.

Bhagat, A., B. Bolton, J. Lu, 2012. Size, leverage and risk-taking of financial institutions, SSRN Working Paper. Available at: http://papers.ssrn.com/sol3/papers.cfm?abstract_id=2122727 (Accessed 9 September 2014)

Brunnermeier, K. M., 2009. Deciphering the liquidity and credit crunch 2007-2008. Journal of Economic Perspectives. 23, 77-100.

Chen, C. R., T. L. Steiner, A. M. Whyte, 2006. Does stock option-based executive compensation induce risk-taking? An analysis of the banking industry. Journal of Banking and Finance. 30, 915-945.

Coles, J. L., N. D. Daniel, L. Naveen, 2006. Managerial incentives and risk-taking. Journal of Financial Economics. 79, 431-68.

Conyon, M.J., K. J. Murphy, 2000. The prince and the pauper? CEO pay in the United States and United Kingdom. Economic Journal. 110, 640-671.

Core, J., W. Guay, 1999. The use of equity grants to manage optimal equity incentive levels. Journal of Accounting and Economics. 28,151-184.

Dietl, H. M., M. Grossmann, M. Lang, S. Wey, 2013. Incentive effects of bonus taxes in a principal-agent model. Journal of Economic Behavior \& Organization. 89, 93104.

Directive 2013/36/EU, Official Journal of European Union, L 176/338. Available at http://eur-

lex.europa.eu/LexUriServ/LexUriServ.do?uri=OJ:L:2013:176:0338:0436:EN:PDF

(Accessed 25 August 2014)

EBA Report High Earners 2012 Data. Available at http://www.eba.europa.eu/documents/10180/16145/EBA+Report+High+Earners+201 2.pdf (Accessed 25 August 2014)

EBA Report High Earners 2010 \& 2011 Data https://www.eba.europa.eu/documents/10180/16145/EBA-ReportHigh_Earner_results.pdf (Accessed 25 August 2014) 
Fahlenbrach, R. R., M. Stulz, 2011. Bank CEO incentives and the credit crisis. Journal of Financial Economics. 99, 11-26.

Financial Services Authority, 2009. Reforming remuneration practices in financial services. CP09/10.

Fortin, R., G. M. Goldberg, G. Roth, 2010. Bank risk taking at the onset of the current banking crisis. The Financial Review. 45, 891-913.

Guay, W.R., 1999. The sensitivity of CEO wealth to equity risk. Journal of Financial Economics. 53, 43-71.

Houston, J. F., C. James, 1995. CEO compensation and bank risk: is compensation in banking structured to promote risk taking? Journal of Monetary Economics. 36, 405431.

Huang, J., Clemens S., Hanjiang Z., 2011. Risk shifting and mutual fund performance. Review of Financial Studies. 24, 2575-2616.

Jeitschko, T. D., S. D. Jeung, 2005. Incentives for risk-taking in banking: a unified approach. Journal of Banking and Finance. 29, 759-777.

John, K., Y. Qian, 2003. Incentive features in CEO compensation in the banking industry. FRBNY Economic Policy Review. 9 (1), 109-121.

Laeven, L., R. Levine, 2009. Bank governance, regulation and risk taking. Journal of Financial Economics. 93, 259-275.

Lee, E., K. Stathopoulos, K. Vonatsos, 2007. UK executive stock option valuation: a conditional model. Corporate Governance: An International Review. 15, 1469-1479.

Louise, G., 2011. Corporate Finance Law: Principles and Policy. Oxford: Portland.

Marshall, J., 2009. Executive remuneration in UK banking. House of Commons No. SN/BT/04970.

Merton, R. C., 1977. Analytical derivation of the cost of deposit insurance and loan guarantees: an application of modern option pricing theory. Journal of Banking and Finance. 1, 3-11.

Murphy, K., 2013. Regulating banking bonuses in the European Union: A case study in unintended consequences. Center in Law, Economics and Organization Research Papers Series, No. C13-8, April 4.

Myers, S., 1977. Determinants of Corporate Borrowing. Journal of Financial Economics. 5, 147-175.

Pathan, S., 2009. Strong boards, CEO power and bank risk-taking. Journal of Banking and Finance. 33, 1340-1350. 
Ponce, J., 2010. Lender of last resort policy: what reforms are necessary? Journal of Financial Intermediation. 19, 188-206.

Rajgopal, S., T. Shevlin, 2002. Empirical evidence on the relation between stock option compensation and risk taking. Journal of Accounting and Economics. 33, 145171.

Rogers, D. A., 2002. Does executive portfolio structure affect risk management? CEO risk-taking incentives and corporate derivatives usage. Journal of Banking and Finance. 26, 271-295.

Walker Review Secretariat, 2009. A review of corporate governance in UK banks and other financial industry entities. 


\begin{abstract}
APPENDIX
Variable definitions

Variable Name

Bank executives' stock options

Vega

Delta

\section{Definitions}

Option-induced risk-taking incentives; the average sensitivity of executives' stock option to equity risk.

Option-induced performance incentives; the average sensitivity of executives' stock option to the bank's stock price.
\end{abstract}

Banks' risk measures

Total risk

z-score

\section{Control variables}

Bank size

Derivatives hedger

Derivatives trader

$\%$ Non-Exec

\%Ownership
The standard deviation or volatility of the banks' stock returns.

The banks' return on assets plus the capital asset ratio, divided by standard deviations of returns. The score represents the inverse of the probability of insolvency; banks with a higher z-score are more financially stable.

The natural logarithm of total assets.

A dummy variable that equals one if the banks use derivatives for hedging, and zero otherwise.

A dummy variable that equals one if the banks use derivatives for trading, and zero otherwise.

Number of non-executive directors divided by the number of board members.

The percentage of equity ownership held by executives. 
TABLE 1

Sample Selection and Description

\begin{tabular}{|c|c|c|c|c|}
\hline \multicolumn{5}{|c|}{ Panel A. Sample Selection } \\
\hline & \multicolumn{3}{|c|}{$\begin{array}{l}\text { Banks incorporated in: } \\
\text { Inside EEA }\end{array}$} & \multirow[b]{2}{*}{ Total } \\
\hline & UK & Ex-UK & Outside EEA & \\
\hline $\begin{array}{l}\text { Banks authorised to accept deposits in the } \\
\text { United Kingdom (UK) }\end{array}$ & $150(45 \%)$ & $98(30 \%)$ & $83(25 \%)$ & 331 \\
\hline \multirow[t]{2}{*}{$\begin{array}{l}\text { At least one annual report published } \\
\text { during the } 2005-2008 \text { period was not } \\
\text { available }\end{array}$} & $114(56 \%)$ & $66(33 \%)$ & $22(11 \%)$ & 202 \\
\hline & $36(28 \%)$ & $32(25 \%)$ & $61(47 \%)$ & 129 \\
\hline $\begin{array}{l}\text { Usage/non-usage of stock options was not } \\
\text { disclosed during 2005-2008 }\end{array}$ & $25(36 \%)$ & $11(16 \%)$ & $33(48 \%)$ & 69 \\
\hline Total banks & $11(18 \%)$ & $21(35 \%)$ & $28(47 \%)$ & 60 \\
\hline \multirow[t]{4}{*}{ Total bank-years (i.e. $60 \times 4$ years) } & & & & 240 \\
\hline & \multicolumn{3}{|c|}{ Panel B. Sample Description } & \\
\hline & \multicolumn{3}{|c|}{$\begin{array}{l}\text { Bank-years incorporated in: } \\
\text { Inside EEA }\end{array}$} & \\
\hline & UK & Ex-UK & Outside EEA & Total \\
\hline $\begin{array}{l}\text { Bank-years disclosed not using stock } \\
\text { options }\end{array}$ & $4(5 \%)$ & $24(32 \%)$ & $48(63 \%)$ & 76 \\
\hline $\begin{array}{l}\text { Bank-years did not grant stock options } \\
\text { during 2005-2008 }\end{array}$ & $1(17 \%)$ & $0(0 \%)$ & $5(83 \%)$ & 6 \\
\hline $\begin{array}{l}\text { Bank-years disclosed as using but did not } \\
\text { grant stock options during 2005-2008 }\end{array}$ & $4(11 \%)$ & $20(56 \%)$ & $12(33 \%)$ & 36 \\
\hline Bank-years without stock option grants & $9(8 \%)$ & $44(37 \%)$ & $65(55 \%)$ & 118 \\
\hline $\begin{array}{l}\text { Bank-years with stock option grants and } \\
\text { disclosure of details during 2005-2008 }\end{array}$ & $35(29 \%)$ & $40(33 \%)$ & $47(38 \%)$ & 122 \\
\hline Total bank-years & $44(18 \%)$ & $84(35 \%)$ & $112(47 \%)$ & 240 \\
\hline
\end{tabular}

The table reports the sample selection criteria and description for the sample of 240 bank-years during 2005-2008. The full sample contains 122 bank-years that granted stock options and 118 bank-years that did not grant stock options to their executive directors. 
TABLE 2

Descriptive statistics

\begin{tabular}{lrrrrr}
\hline & $N$ & Mean & Std. Dev. & Min & Max \\
\cline { 2 - 5 } Option/Tot. Pay & 240 & 0.24 & 0.32 & 0.00 & 0.98 \\
Tot. Option Value (£000) & 240 & 5,252 & 11,000 & 0.0 & 70,600 \\
Vega & 240 & 0.03 & 0.07 & 0.0 & 0.41 \\
Vega (£000) & 240 & 2 & 7 & 0.0 & 75 \\
Delta & 240 & 0.24 & 0.37 & 0.0 & 0.99 \\
Delta (£000) & 240 & 65 & 177 & 0.0 & 1,427 \\
Stock Volatility & 240 & 0.019 & 0.011 & 0.004 & 0.072 \\
Ln(z-score) & 240 & 1.23 & 0.87 & -2.81 & 5.27 \\
Ln(Size) & 240 & 25.16 & 1.86 & 18.54 & 28.39 \\
Derivatives Hedger & 240 & 0.08 & 0.26 & 0.00 & 1.00 \\
Derivatives Trader & 240 & 0.17 & 0.37 & 0.00 & 1.00 \\
\%Non-Exec & 240 & 0.80 & 0.17 & 0.27 & 1.00 \\
\%Ownership & 240 & 0.004 & 0.009 & 0.000 & 0051 \\
\hline
\end{tabular}

The table reports the descriptive statistics for the sample of 240 bank-years during 2005-2008. The full sample contains 122 bank-years that granted stock options and 118 bank-years that did not grant stock options to their executive directors. All variables are defined in the Appendix. 
TABLE 3

Bank risk and option-induced risk-taking incentives (vega)

\begin{tabular}{|c|c|c|c|c|}
\hline & \multicolumn{4}{|c|}{ Period: $2005-2008$} \\
\hline & \multicolumn{2}{|c|}{ Total Risk } & \multicolumn{2}{|c|}{ Z-score } \\
\hline & OLS & 2 SLS & OLS & 2 SLS \\
\hline & (1) & $(2)$ & (3) & $\overline{(4)}$ \\
\hline \multirow[t]{2}{*}{ Vega } & $0.011 * * *$ & $0.035 * * *$ & $-0.136^{*}$ & $-0.303 * * *$ \\
\hline & $(0.000)$ & $(0.000)$ & $(0.077)$ & $(0.007)$ \\
\hline \multirow[t]{2}{*}{ Delta } & $-0.004 * * *$ & $-0.009 * * *$ & $0.062 *$ & \\
\hline & $(0.007)$ & $(0.004)$ & $(0.095)$ & \\
\hline \multirow[t]{2}{*}{ Bank Size } & $-0.004 * * *$ & -0.001 & $-0.201 * * *$ & $-0.142 * * *$ \\
\hline & $(0.005)$ & $(0.195)$ & $(0.000)$ & $(0.000)$ \\
\hline \multirow[t]{2}{*}{$\%$ Non-Exec } & $-0.101 * * *$ & $-0.037 * * *$ & & \\
\hline & $(0.000)$ & $(0.002)$ & & \\
\hline \multirow[t]{2}{*}{ Derivatives Trader } & $0.018 * * *$ & 0.004 & $-0.429 * * *$ & 0.035 \\
\hline & $(0.004)$ & $(0.500)$ & $(0.005)$ & $(0.803)$ \\
\hline \multirow[t]{2}{*}{ Derivatives Hedger } & & & -0.319 & 0.010 \\
\hline & & & $(0.176)$ & $(0.960)$ \\
\hline \multirow[t]{2}{*}{ \%Ownership } & $-0.004 * * *$ & $-0.001 * *$ & $0.053 * *$ & $0.068 * * *$ \\
\hline & $(0.000)$ & $(0.024)$ & $(0.014)$ & $(0.000)$ \\
\hline \multirow[t]{2}{*}{ Intercept } & $0.169 * * *$ & $0.078 * *$ & $6.600 * * *$ & $5.571 * * *$ \\
\hline & $(0.000)$ & $(0.014)$ & $(0.000)$ & $(0.000)$ \\
\hline Country dummy & Yes & Yes & Yes & Yes \\
\hline Year dummy & Yes & Yes & Yes & Yes \\
\hline No. of observations & 240 & 240 & 240 & 240 \\
\hline$R^{2}$ & 0.45 & 0.02 & 0.56 & 0.25 \\
\hline Max vif & 4.28 & & 4.31 & \\
\hline Mean vif & 1.74 & & 1.65 & \\
\hline
\end{tabular}

The table presents the results for OLS (Columns 1 and 3) and 2SLS (Columns 3 and 4) regressions for a sample of 240 bank-years during 2005-2008. The dependent variable is banks' total risk (Columns 1 and 2) and insolvency risk (Columns 3 and 4). Total risk is measured by the standard deviation of stock returns. A lower z-score indicates a higher insolvency risk. Vega measures bank executives' risktaking incentives induced by stock options. Delta measures bank executives' performance incentives. $\%$ Ownership is the percentage of equity ownership held by executives. Other variables are defined in the Appendix. $* * * \mathrm{p}<0.01, * * \mathrm{p}<0.05$ and ${ }^{*} \mathrm{p}<0.10$. The $p$-values are in parentheses. 
TABLE 4

Banks' total risk and option-induced risk-taking incentives (vega) during non-crisis, pre-crisis and crisis periods

\begin{tabular}{|c|c|c|c|}
\hline & $\begin{array}{l}\text { Non- } \\
\text { crisis }\end{array}$ & $\begin{array}{r}\text { Pre- } \\
\text { Crisis }\end{array}$ & Crisis \\
\hline & 2005 & 2006 & $\begin{array}{r}2007- \\
2008\end{array}$ \\
\hline & (1) & (2) & (3) \\
\hline \multirow[t]{2}{*}{ Vega } & 0.008 & $0.025 * * *$ & $0.015 * * *$ \\
\hline & $(0.579)$ & $(0.009)$ & $(0.001)$ \\
\hline \multirow[t]{2}{*}{ Delta } & -0.004 & $-0.007 *$ & $-0.004 *$ \\
\hline & $(0.461)$ & $(0.061)$ & $(0.063)$ \\
\hline \multirow[t]{2}{*}{ Bank Size } & -0.003 & -0.003 & -0.003 \\
\hline & $(0.418)$ & $(0.346)$ & $(0.171)$ \\
\hline \multirow[t]{2}{*}{$\%$ Non-Exec } & $-0.107 *$ & -0.062 & $-0.070 * *$ \\
\hline & $(0.057)$ & $(0.139)$ & $(0.010)$ \\
\hline \multirow[t]{2}{*}{ Derivatives Trader } & $0.033^{*}$ & $0.039 * *$ & 0.015 \\
\hline & $(0.093)$ & $(0.021)$ & $(0.237)$ \\
\hline \multirow[t]{2}{*}{ Intercept } & $0.199 *$ & 0.160 & $0.153 * * *$ \\
\hline & $(0.080)$ & $(0.100)$ & $(0.010)$ \\
\hline Country dummy & Yes & Yes & Yes \\
\hline No. of observations & 60 & 60 & 120 \\
\hline$R^{2}$ & 0.39 & 0.55 & 0.36 \\
\hline Max vif & 7.44 & 5.59 & 3.59 \\
\hline Mean vif & 1.88 & 1.82 & 1.74 \\
\hline
\end{tabular}

The table presents the results for OLS regressions for a sample of 60 banks (Columns 1 and 2) and 120 bank-years (Column 3). The dependent variable is banks' total risk as measured by the standard deviation of stock returns. Vega measures bank executives' risk-taking incentives induced by stock options. Delta measures bank executives' performance incentives. Other variables are defined in the Appendix. $* * * p<0.01, * * p<0.05$ and $* \mathrm{p}<0.10$. The $p$-values are in parentheses. 
TABLE 5

Banks' insolvency risk and option-induced risk-taking incentives (vega) during non-crisis, pre-crisis and crisis periods

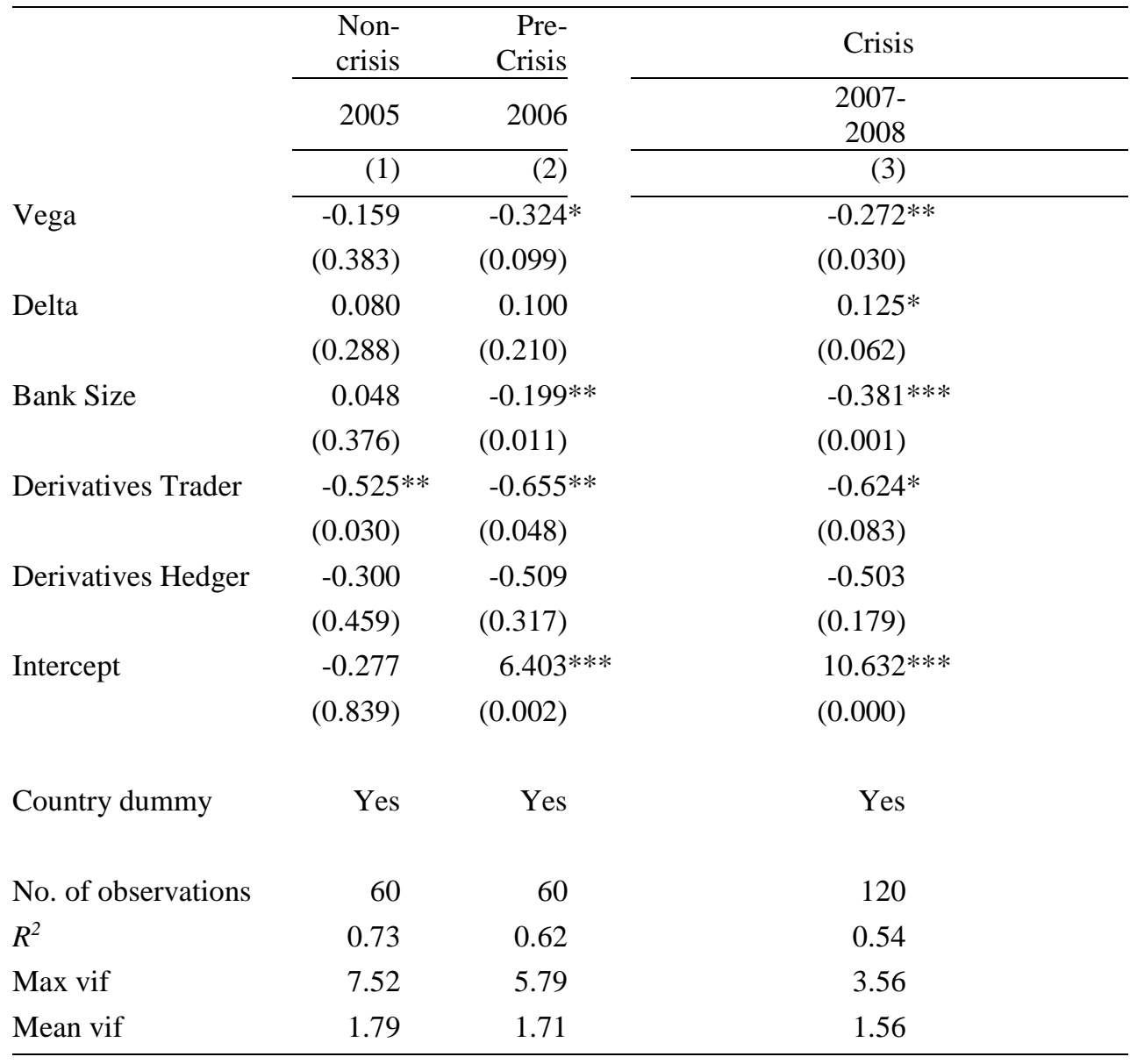

The table presents the results for OLS regressions for a sample of 60 banks (Columns 1 and 2) and 120 bank-years (Column 3). The dependent variable is the inverse of insolvency risk (measured by z-score). A lower z-score indicates a higher insolvency risk. Vega measures bank executives' risk-taking incentives induced by stock options. Delta measures bank executives' performance incentives. Other variables are defined in the Appendix. $* * * \mathrm{p}<0.01, * * \mathrm{p}<0.05$ and ${ }^{*} \mathrm{p}<0.10$. The $p$-values are in parentheses. 